Available online on 15.05.2020 at http://jddtonline.info
Open Access to Pharmaceutical and Medical Research
unrestricted non-commercial use, provided the original work is properly cited

Open $\odot$ Access

Research Article

\title{
Preparation and Evaluation of Chewable Tablets of Syzygium cumini Seed Powder
}

\author{
Palakurthi Sushesh Srivatsa*, Jakka Deeksha, Singh Harpreeth, Bollavaram Sahithi, B Siri Nandini, \\ Pinnamraju Durga Nithya*, Konde Abbulu
}

CMR College of Pharmacy, Hyderabad, Telangana, 501-401, India

\begin{abstract}
Aim of this study is to develop chewable tablets of Syzygium cumini seed powder. It has been chosen to do so as there are no oral solid dosage forms of this seed powder developed so far. There are numerous health benefits and nutrient properties of this seed powder, thus it can be used as a nutraceutical. Phytochemical screening of the Syzygium cumini seed powder has been conducted and the various phyto constituents present were detected. Seven different formulations have been developed by direct compression method out of which five were optimized. All these formulations were developed with Syzygium cumini seed powder as the active ingredient and lactose, acacia, glucose, talc, magnesium stearate, hydroxy propyl methyl cellulose, sodium alginate, guar gum and stevia were used as excipients. Various evaluations tests were performed to check the stability of the chewable tablets. Fourier Transform Infrared Spectroscopy (FTIR) analysis was conducted to check the interactions among the seed powder and the excipients. Anti-bacterial activity of the chewable tablets was tested against three different species of bacteria (Escherichia coli and Bacillus subtilis) by agar diffusion method. It is concluded that the Syzygium cumini seed powder and the developed chewable tablets were active against Escherichia coli and Bacillus subtilis.
\end{abstract}

Keywords: Syzygium cumini, Chewable tablet, anti-bacterial activity

Article Info: Received 10 March 2020; Review Completed 13 April 2020; Accepted 21 April 2020; Available online 15 May 2020

Cite this article as:

Palakurthi SS, Jakka D, Singh H, Bollavaram S, B SN, Pinnamraju DN, Konde A, Preparation and Evaluation of Chewable Tablets of Syzygium cumini Seed Powder, Journal of Drug Delivery and Therapeutics. 2020; 10(3):58-64 http://dx.doi.org/10.22270/jddt.v10i3.4069

*Address for Correspondence: Palakurthi Sushesh Srivatsa, Pinnamraju Durga Nithya

CMR College of Pharmacy, Hyderabad, Telangana, 501-401

\section{INTRODUCTION}

Syzygium cumini, commonly known as jambolan, Java plum, black plum or jamun, is an evergreen tropical tree in the flowering plant family Myrtaceae. It is native to the Indian Subcontinent, adjoining regions of Southeast Asia, China and Queensland. The name of the fruit is sometimes mistranslated as blackberry, which is a different fruit in an unrelated order[1]. The seed of the fruit is used in various alternative healing systems like Ayurveda, Unani and Chinese medicine. Various phytochemical compounds identified in Syzygium cumini seed powder are tabulated in table 1 . Wine and vinegar are also made from the fruit and it is also a high source in vitamin A and vitamin C[2]. The seed powder is reported to have nutraceutical properties[3], as it contains significant amounts of carbohydrates, proteins, fats, fiber, calcium and phosphorus[2] and other parts of this plant like leaves were reported to have anti-platelet[4], anticoagulant[5], anti-hypertriglyceridemic effect[6], antiinflamatory[7] properties and anti-diabetic activity[8-10]. Syzygium cumini seed powder is composed of phenols, tannins, which are mainly responsible for the antimicrobial activity of the seed powder. The seed powder is active against various species of microbes like E. coli, Bacillus subtilis, Streptococcus and Staphylococcus[11, 12]

Despite its overwhelming potential, to the best of our knowledge, there are no formulations of Syzygium cumini seed powder reported. Goal of the present study is to develop chewable tablets of seed powder of syzygium cumini. Chewable tablets are more stable compared to liquid dosage forms, and as they start disintegrating in the oral cavity and slowly release the drug, the active components of the see powder in this case, and elicit its anti-bacterial activity against the bacteria residing in the oral cavity, such as E. coli, Bacillus subtilis, Streptococcus and Staphylococcus, Pseudomonas, Lactobacillus and Atopobium species. Seven different chewable tablet formulations were prepared by changing the tablet composition and the formulations were subjected to quality control tests including weight variation, hardness, friability, disintegration. Antibacterial activity of the formulations was tested against E. coli and Bacillus subtilis. 
Table 1: Phytochemical compounds identified in Syzygium cumini seed powder

\begin{tabular}{|l|l|l|}
\hline S. No & Class of metabolite & Compounds identified \\
\hline 1 & Flavonoids & Quercetin, rutin, 3,5,7,4-tetrahydroxy flavanone \\
\hline 2 & Phenolic acids & Caffeic acid, ellagic acid, ferulic acid, gallic acid \\
\hline 3 & Tannins & HHDP-galloyl glucose, trigalloyl glucose \\
\hline 4 & Terpenes & Citronellol, geraniol, hotrienol, nerol, $\beta$-phenylethanol, phenylpropanal \\
\hline 5 & Anthocyanins & Cyanidin, delfinidin, petudinin \\
\hline
\end{tabular}

\section{MATERIALS \& METHODS}

\section{Materials}

Seeds from the domestically grown Syzygium cumini plant were collected, shade dried, powdered and sieved. The authentication of the plant was obtained from Botanical Survey of India (BSI), Deccan Regional Centre, Hyderabad, India. Stevia powder was purchased from The Herbs $\mathrm{N}$ Spices, Neemuch, Madhya Pradesh, India. Lactose, acacia, glucose, talc, magnesium stearate, Hydroxy Propyl Methyl Cellulose (HPMC), sodium alginate, guar gum, polyethylene glycol (PEG) 400, dichloromethane and ethanol were purchased from S.D Fine Chem Ltd. Mumbai, Maharashtra, India.

\section{Methods}

Phytochemical Screening: The seed powder was subjected to phytochemical analysis by performing tests for alkaloids, cardiac glycosides, flavonoids, steroids/triterpenoids, tannins and phenols and saponins as reported previously[13].

Formulation of chewable tablets of Syzygium cumini seed powder: Tablets were formulated by direct compression method[14-16]. Seven formulations were formulated with constant amount of seed powder and varied concentrations of excipients as shown in table 3. The excipients and the seed powder were added into a mortarand-pestle in the decreasing order of their weights, mixed thoroughly and the powder was evaluated for angle of repose, bulk density, tapped density and Carr's index which are tabulated in table 2 . Chewable tablets were formulated using $\mathrm{R} \& \mathrm{D}$ scale tablet punching machine (Karpatavastatinvati Engineering Ltd.).

\section{Pre-Compression evaluation[14]:}

Angle of repose: The angle of repose of the powder blend was calculated using funnel method[17]. A known amount of the powder blend was placed in a glass funnel. The height of the funnel was adjusted in such a way that the tip of the funnel just touched the apex of the powder blend. The powder blend could flow through the funnel freely. Diameter of the powder pile was measured, and angle of repose was calculated using the following equation[17].

\section{$\operatorname{Tan} \theta=\mathrm{h} / \mathrm{r}$}

Where $\operatorname{Tan} \theta$ is the angle of repose; $h$ is the height and $r$ is the radius of the powder mass

Determination of Bulk density and Tapped density: A 20 $\mathrm{mg}$ of the powder was placed into a $100 \mathrm{~mL}$ measuring cylinder and the initial volume was observed. The cylinder could fall onto a hard surface from the height of $2.5 \mathrm{~cm}$ with a time interval of 2 sec. Tapping was continued until no further change in volume was noted. The bulk density and tapped density were calculated using the following formula[14]:
Bulk density $=\mathrm{W} /$ Vo; Tapped density $=\mathrm{W} / \mathrm{VF}$

Where $\mathrm{W}$ =weight of the powder; Vo =initial volume of powder; $\mathrm{VF}$ = Final volume of powder

The ratio of the tapped density to the bulk density is called Hausner's ratio. Hausner's ratio $>1.25$ indicates good flowability of the powder.

Compressibility Index: Compressibility index or Carr's index is an important measure that can be obtained from the bulk and tapped density. It is calculated by the equation, Carr's index $=$ (Tapped density - Bulk density $) /$ Tapped density. For a material to be more flowable it needs to be less compressible. A material having value of less than $20 \%$ has good flow properties[14].

\section{Quality control tests for tablets:}

Weight variation: Weight variation test is done by weighing 20 tablets individually. The average tablet weight was calculated and compared with the individual weigh. This procedure has been followed as per USP.

Tablet hardness: The resistance of tablets to break under conditions of storage, transportation and handling before usage depends on tablet's hardness. The hardness of each batch was tested by randomly testing the tablets (how many per batch) using Monsanto hardness tester (Make: Pharma Chem Machineries). The hardness was measured in terms of $\mathrm{Kg} / \mathrm{cm}^{2}$.

Friability: The device subjects the tablets to abrasion and shock by utilizing a plastic chamber that revolved at $25 \mathrm{rpm}$. Sample of 10 tablets, whose weight is measured previously, were dropped in the friabilator from a distance of 6 inches which was then operated for 100 revolutions and the tablets were dusted and reweighed[14]. According to USP, to pass the test, the tablet should not lose more than $1 \%$ of their weight.

$\%$ friability $=[(\mathrm{W} 1-\mathrm{W} 2) / \mathrm{W} 1] * 100$

Where $\mathrm{W} 1=$ Weight of tablets before test

W2= Weight of tablets after test

Disintegration Test: Disintegration test was conducted by using USP II Disintegration test apparatus. One tablet is placed in each tube and the basket rack was positioned in a 1 -litre beaker of water at $37 \pm 2^{\circ} \mathrm{C}$. A standard motor-driven device is used to move the basket assembly containing the tablets up and down through a distance of 5 to $6 \mathrm{~cm}$ at a frequency of 28 to 32 cycles per minutes. The time taken for the tablet to disintegrate completely was recorded.

Determination of Anti-bacterial activity: Agar well diffusion method was adopted for calculating the zone inhibited by the formulated chewable tablets[18, 19]. In this method, glassware was sterilized in a hot air oven at $160^{\circ} \mathrm{C}$ for one-hour, nutrient media was prepared and autoclaved at $120^{\circ} \mathrm{C}$ for $20 \mathrm{~min}$. Cool the media and allowed it to solidify. 
The culture was inoculated by pour plate method and a bore was made at the center using a sterile borer, in which the formulation was placed, this process should be carried out in an aseptic chamber. The nutrient medium was incubated at $37^{\circ} \mathrm{C}$ for 24 hours followed by the measurement of the zone of inhibition by the zone reader.

\section{RESULTS AND DISCUSSION:}

Phytochemical Screening: Phyto constituents like alkaloids, cardiac glycosides, flavonoids, steroids, tannins and phenols were found to be present whereas saponins tested to be absent. The results are depicted in table 2 .

\section{Table 2: Phytochemical screening of Syzygium cumini seed powder}

Phyto constituents like alkaloids, cardiac glycosides, flavonoids, steroids, tannins and phenols were found to be present whereas saponins were tested to be absent.

\begin{tabular}{|l|l|l|}
\hline S. No & Test & Result \\
\hline 1 & $\begin{array}{l}\text { Detection of alkaloids: } \\
\text { 1) Mayer's Test } \\
\text { 2) Dragendroff's test } \\
\text { 3) Wagner's Test } \\
\text { 4) Hager's Test }\end{array}$ & + \\
& $\begin{array}{l}\text { Detection of Cardiac glycosides: } \\
\text { 1) Kedde's test } \\
\text { 2) Baljet's test }\end{array}$ & + \\
\hline 2 & $\begin{array}{l}\text { Detection of flavonoids: } \\
\text { 1) Shinoda Test }\end{array}$ & + \\
\hline 3 & $\begin{array}{l}\text { Detection of saponins: } \\
\text { 1) Froth Formation test }\end{array}$ & + \\
\hline 4 & $\begin{array}{l}\text { Detection of steroids/ } \\
\text { Triterpenoids: } \\
\text { 1) Salkowski test } \\
\text { 2) Sulphur powder test } \\
\text { 3) Liebermann bucchard test }\end{array}$ & + \\
\hline 5 & Detection of tannins & + \\
\hline 6 & Detection of Phenols & + \\
\hline 7 & & + \\
\hline
\end{tabular}

\section{Preparation and evaluation of chewable tablets:}

Chewable tablets of syzygium cumini seed powder have been prepared by direct compression method, depicted in figure 1 . The composition of these chewable tablets is shown in table 3. Lactose was used as a diluent to increase the bulk of the powder mixture. Acacia acts as a binding agent which holds the powder material together by adhesion or cohesion. To mask the taste of the seed powder, glucose was used as a sweetening agent. Talc was incorporated as a glidant and magnesium stearate was used as a lubricant. While the powder mixture was compressible directly without adding the binder, the tablets were unstable separating into layers (also called lamination of the tablet). When $50 \mathrm{mg}(10 \%)$ of the he binding agent was incorporated, the hardness of the resulting tablets was poor $\left(<1 \mathrm{~kg} / \mathrm{Cm}^{2}\right)$, which might be due to insufficient binder. To improve the stability of the tablets, the binder concentration was further increased to $17 \%$ keeping the quantity of other excipients constant. A total of seven formulations were made using R \& D scale tablet punching machine (Karpatavastatinvati Engineering Ltd.). Color, weight variation, hardness, friability, thickness and disintegration time were evaluated and the data are presented in table 4.

All the evaluations tests have been performed from F3 through F7 as F1 and F2 failed in the pre-formulation stage itself. The physical appearance of the tablets was smooth and uniform with no cracks and with a diameter of $1 \mathrm{~cm}$. To ensure each tablet contains desired amount of seed powder, weight variation test was conducted. The tablets met the USP specifications that not more than 2 tablets are outside the percentage limit which is $\pm 5 \%$. All the tablets were within $\pm 10 \%$ variation from the average weight of the formulation. Friability is generally referred to loss in weight of tablet in the containers due to removal of fines from the tablets surface. Friability generally reflects poor cohesion of tablets ingredients. Friability test was performed with 10 tablets of each formulation. The average weight loss of the tablets following friability testing was with $1 \%$ of the average weight of the formulation indicating the physical stability of the tablets when exposed to mechanical shock and attrition. Hardness test was performed to provide a measure of the tablet's strength as the tablets need to be hard enough for packing and moving, but no so hard creating difficulty during chewing. The hardness ranged from 2.5 to $3.0 \mathrm{~kg} / \mathrm{cm}^{2}$. Thickness of the tablets was found to be from 0.76 to $0.78 \mathrm{~cm}$ from F3 to F7 which might affect disintegration.

Disintegration time of chewable tablets should be short enough to prevent choking in case the patient does not completely chew it. Six tablets were tested for disintegration from each formulation. The disintegration time of the tablets ranged from 22 to $25 \mathrm{~min}$. All the formulations F3 to F7 have been show to stable and meet the United States Pharmacopoeia (USP) quality control standards for chewable tablets. It should be noted, however, that in F6 stevia was used to replace glucose, which makes it suitable for diabetic patients. The formulation F7 has a coloring agent to improve its aesthetic appeal. The results of all the evaluation tests have been tabulated in table 5 . 


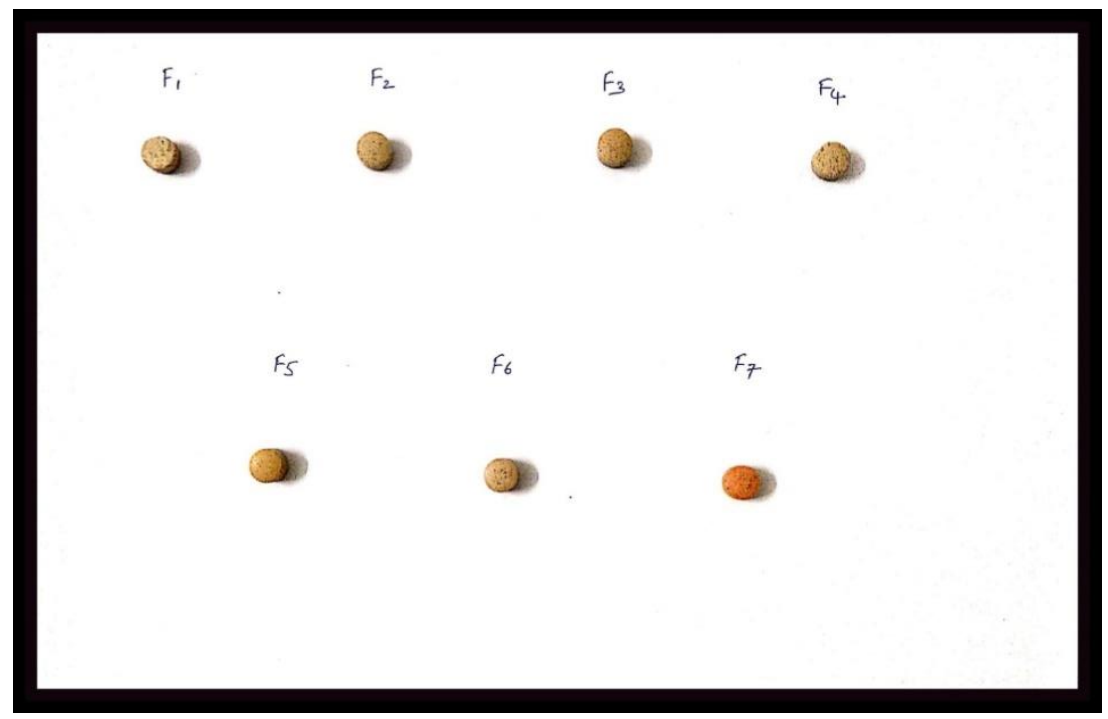

Figure 1: Chewable tablets of Syzygium cumini seed powder

Seven different formulations of chewable tablets were developed and evaluated.

Table 3: Flow Properties of formulation for chewable tablets

All the pre-formulation evaluation test parameters have been tested and the flow was infered to be excellent. Chewable tablets were formulated as the powder blend had excellent flow properties.

\begin{tabular}{|l|l|l|}
\hline S. No & Evaluation test & Test values \\
\hline 1 & Bulk density & $0.107 \mathrm{gm} / \mathrm{ml}$ \\
\hline 2 & Tapped density & $0.110 \mathrm{gm} / \mathrm{ml}$ \\
\hline 3 & Angle of repose & 26.5 \\
\hline 4 & Husner's ratio & 1.1 \\
\hline 5 & Car's index & 7.69 \\
\hline
\end{tabular}

Table 4: Formulations of chewable tablets

Seven different formulations (F1 to F7) have been formulated with varying amounts of excipients but the quantity of the seed powder was kept constant. Twenty five tablets of each formula were formulated.

\begin{tabular}{|c|c|c|c|c|c|c|c|}
\hline Ingredients & $\begin{array}{l}\text { F1 } \\
\text { (mg) }\end{array}$ & $\begin{array}{l}\text { F2 } \\
\text { (mg) }\end{array}$ & $\begin{array}{l}\text { F3 } \\
\text { (mg) }\end{array}$ & $\begin{array}{l}\text { F4 } \\
\text { (mg) }\end{array}$ & $\begin{array}{l}\text { F5 } \\
\text { (mg) }\end{array}$ & $\begin{array}{l}\text { F6 } \\
\text { (mg) }\end{array}$ & $\begin{array}{l}\text { F7 } \\
\text { (mg) }\end{array}$ \\
\hline Seed powder & 200 & 200 & 200 & 200 & 200 & 200 & 200 \\
\hline Lactose & 200 & 200 & 250 & 250 & 250 & 250 & 250 \\
\hline Acacia & - & 50 & 100 & 100 & 100 & 100 & 100 \\
\hline Glucose & 10 & 10 & - & 10 & 10 & - & - \\
\hline Talc & 05 & 05 & 05 & 05 & 05 & 05 & 05 \\
\hline Stevia & - & - & - & - & - & 10 & 10 \\
\hline Magnesium stearate & 05 & 05 & 05 & 05 & 05 & 05 & 05 \\
\hline Colorant & - & - & - & - & q.s(turmeric) & - & q.s(orange) \\
\hline Total weight(mg) & 420 & 470 & 560 & 570 & 570 & 570 & 570 \\
\hline
\end{tabular}




\section{Table 5: Evaluation of chewable tablets}

Evaluation tests have been performed for five formulations, F3 to F7. Color of the F7 tablets were observed to be orange and that of F5 were pale yellow due to the presence of colorant. Although F4, F6 and F7 found to be the hardest tablets, F3 and F5 formulations too were hard enough. Tablets of F5 were the thickest and that of F3 had the least thickness. All the formulated tablets had uniform diameter whereas the disintegration time varied from $22 \mathrm{~min}$ to $25 \mathrm{~min}$. No evaluation tests have been conducted for F1 and F2 as they did not turnout well during the formulation itself.

\begin{tabular}{|c|c|c|c|c|c|c|c|}
\hline Parameter & F1 & F2 & F3 & F4 & F5 & F6 & F7 \\
\hline Color & $\begin{array}{l}\text { Lamination was } \\
\text { observed. This } \\
\text { may be due to } \\
\text { lack of binder }\end{array}$ & $\begin{array}{l}\text { Poor hardness } \\
\text { due to } \\
\text { insufficient } \\
\text { binder }\end{array}$ & Buff & Buff & Pale yellow & Buff & Orange \\
\hline $\begin{array}{l}\text { Weight } \\
\text { variation }\end{array}$ & & & $\mathrm{P}$ & $P$ & $\mathrm{P}$ & $P$ & $\mathrm{P}$ \\
\hline Hardness & & & $2.5 \pm 0.1$ & $3.0 \pm 0.1$ & $2.8 \pm 0.2$ & $3.0 \pm 0.1$ & $3.0 \pm 0.2$ \\
\hline Friability & & & $P$ & $P$ & $P$ & $P$ & $P$ \\
\hline $\begin{array}{l}\text { Thickness } \\
\text { (cm) }\end{array}$ & & & $\begin{array}{l}0.76 \pm 0 . \\
01\end{array}$ & $0.77 \pm 0.01$ & $0.78 \pm 0.01$ & $0.77 \pm 0.01$ & $0.77 \pm 0.01$ \\
\hline $\begin{array}{l}\text { Disintegration } \\
\text { time(min) }\end{array}$ & & & $25 \pm 0.5$ & $23 \pm 0.5$ & $22 \pm 0.5$ & $22 \pm 0.3$ & $23 \pm 0.5$ \\
\hline Diameter (cm) & & & 1 & 1 & 1 & 1 & 1 \\
\hline
\end{tabular}

\section{Interaction between the seed powder and the excipients of the tablet}

Fourier Transform Infrared Spectroscopy (FTIR) studies were performed to determine the interactions between the active ingredient[20] i.e. Syzygium cumini seed powder and the excipients present in the chewable tablets, if any. FTIR spectra the pure Syzygium cumini seed powder and chewable tablet powder blend are shown in Fig 2 and 3, respectively. It should be noted that the characteristic peaks in the FTIR spectra of the seed powder or the tablet excipients were not altered, indicating that there are no interactions between the active ingredient and the excipients used for formulating chewable tablets. Although the sharpness and wavelength were found to be different, but the peaks were in the same frequency range.

(Ф) SHIMADZU

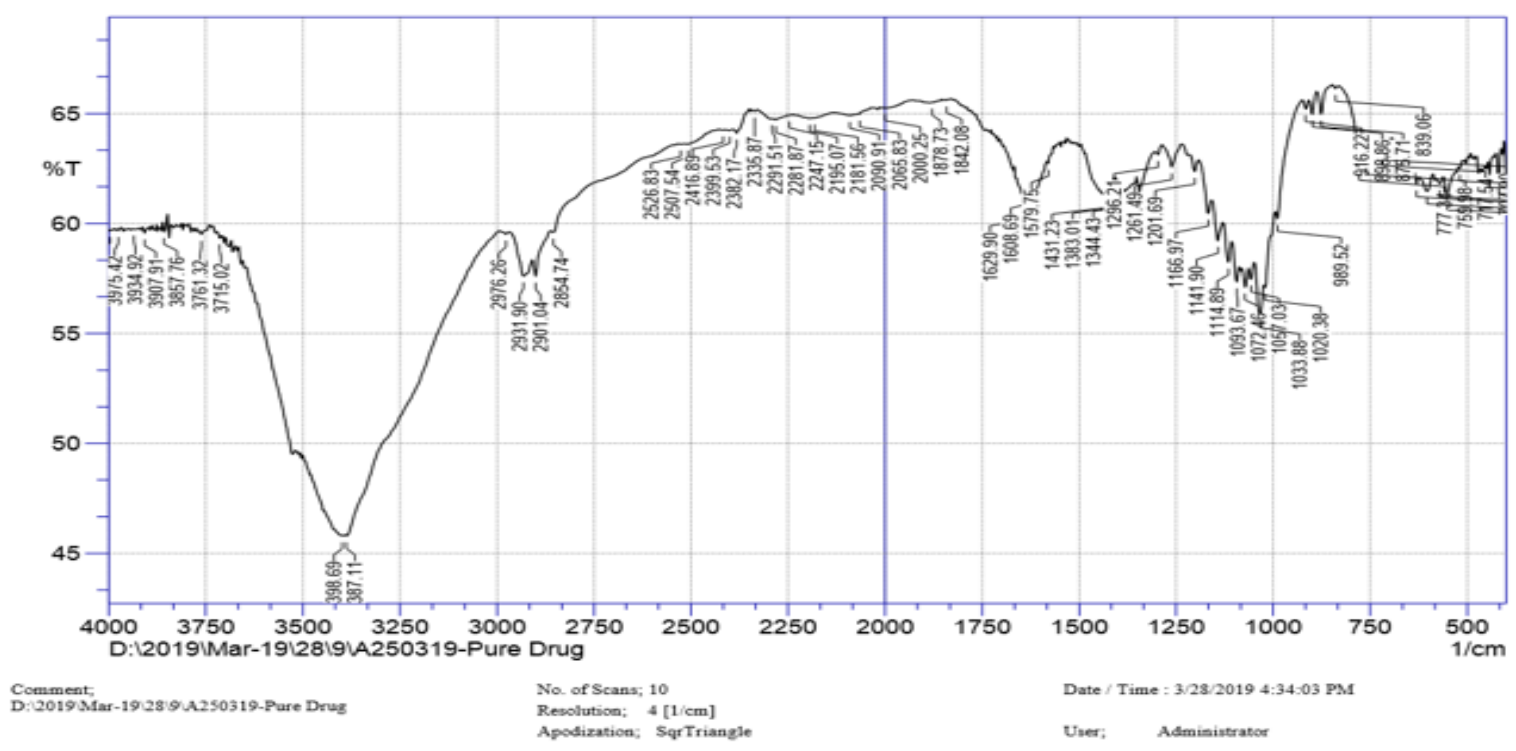

Figure 2: FTIR of Syzygium cumini seed powder 
FTIR of the plain seed powder has been performed and it has been compared with that of the chewable tablet powder blend.

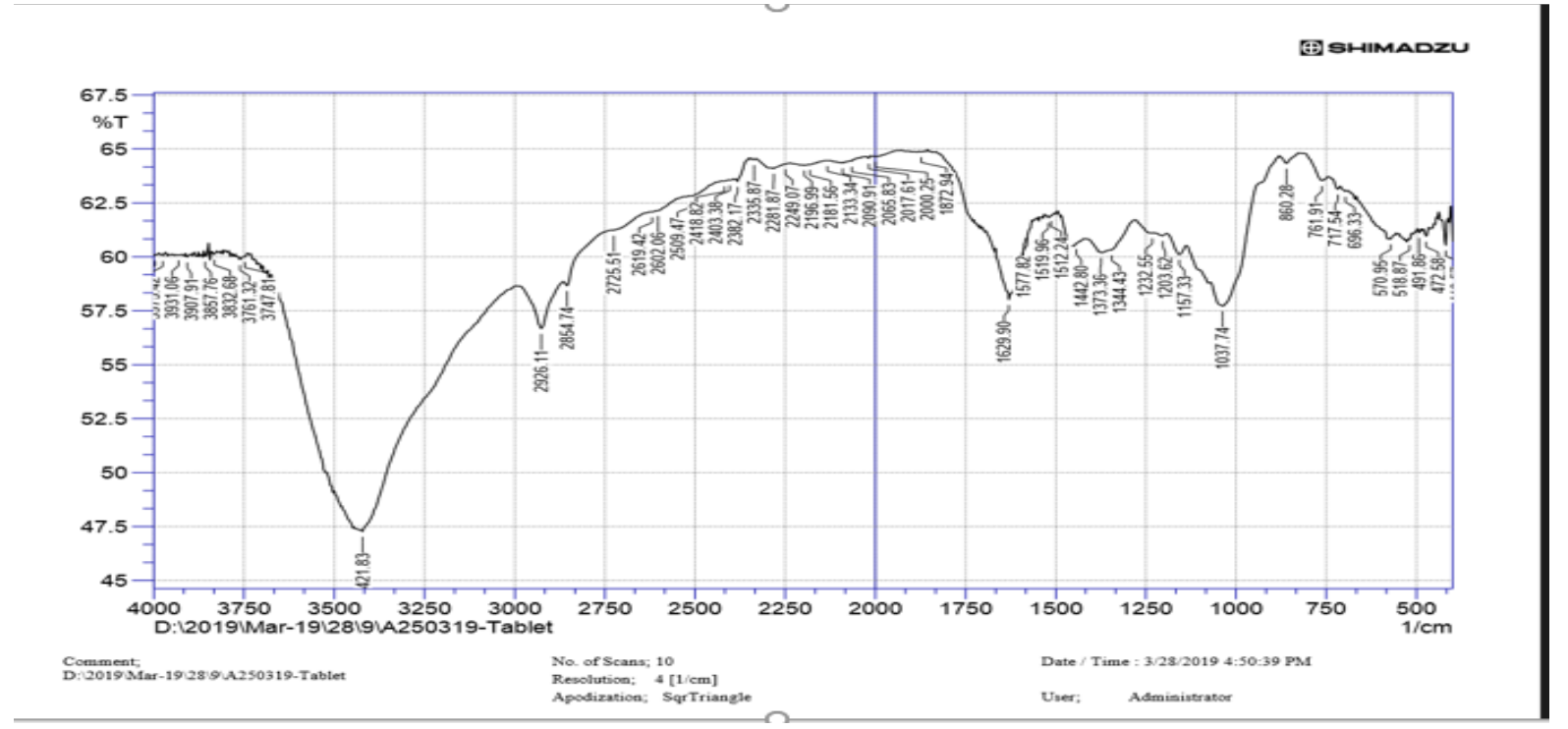

Figure 3: FTIR of Syzygium cumini chewable tablet

When the FTIR of the seed powder is compared to that of the chewable tablet blend it was observed there were no interactions between the seed powder of Syzygium cumini and the excipients of the chewable tablet.

\section{In vitro antibacterial activity against Escherichia coli and Bacillus subtilis.}

The crude seed powder of Syzygium cumini and the formulated chewable tablets were tested for antibacterial activity against Escherichia coli and Bacillus subtilis using agar diffusion method[18] and the results are observer results are shown in figures $4 \& 5$. It has been chosen to perform antibacterial study against Escherichia coli and Bacillus subtilis as these are the bacteria which usually reside in the gut, also in the oral cavity, to some extent, of humans. As it has been formulated as chewable tablets, disintegration starts in the mouth itself which might show its antibacterial effect against the bacteria residing in the oral cavity. Both the crude seed powder and the tablet showed significant antibacterial activity against Escherichia coli and Bacillus subtilis, whose results are represented in table 6. Zone of inhibition was measured using a zone reader and it can be inferred that Syzygium cumini seed powder contains constituents that are responsible for antibacterial activity. The zone of inhibition for Eschericia coli was found to be 3.2 $\mathrm{cm}$ and the zone of inhibition for Bacillus subtilis was found to be $2.7 \mathrm{~cm}$. Data clearly show that our formulation have antimicrobial activity against both Escherichia coli and Bacillus subtilis.

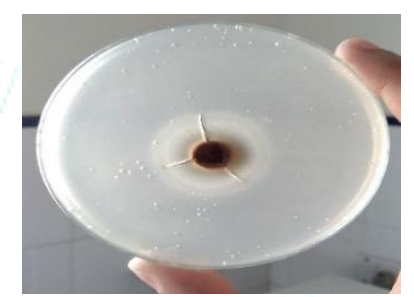

Figure 4: Anti-bacterial activity of Syzygium cumini chewable tablet against Escherichia coli

It can be clearly observed that the chewable tablet is active against Escherichia coli. Zone of inhibition was measured to be $3.2 \mathrm{~cm}$.

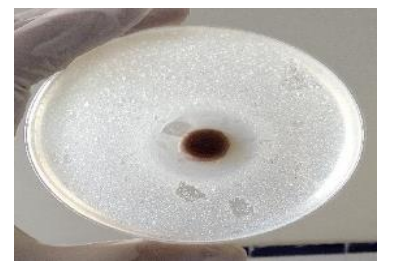

Figure 5: Anti-bacterial activity of Syzygium cumini chewable tablet against Bacillus subtilis.

It can be clearly observed that the chewable tablet is active against Bacillus subtilis. Zone of inhibition was measured to be $2.7 \mathrm{~cm}$

\section{Table 6: Antibacterial activity of Syzygium cumini}

The anti-bacterial activity of both the seed powder and the developed chewable tablets have been tested against three different species of bacteria. Among the three bacteria, both tablets and seed powder showed more activity against Escherichia coli while no activity was observed against Staphylococcus aureus.

\begin{tabular}{|l|l|l|l|l|}
\hline S. No & Test component & \multirow{2}{*}{$\begin{array}{l}\text { Quantity } \\
\text { (mg) }\end{array}$} & & \multicolumn{2}{|l|}{ Zone of inhibition (cm) } \\
\cline { 3 - 5 } & & 570 & Escherichia coli & Bacillus subtilis \\
\hline 1 & Chewable tablet & 3.2 & 2.7 \\
\hline 2 & Seed powder & 200 & 3.4 & 2.8 \\
\hline
\end{tabular}




\section{CONCLUSION:}

Chewable tablets of Syzygium cumini seed powder were formulated and evaluated. Preformulation studies were done to optimize the composition of the tablet powder blend. The FTIR studies showed that there is no interaction between the seed powder and the tablet excipients. The antimicrobial studies revealed that the formulation is having antimicrobial activity against $E$. coli and $B$. Subtlis. The chewable tablet formulation has the potential to be used as a nutraceutical.

Acknowledgement: Author is thankful to the Principal and the management of CMR College of Pharmacy, Hyderabad for providing the necessary facilities for carrying out research work.

Conflict of interest: The authors declare no conflict of interest.

\section{REFERENCES:}

1. Ramya S, K.N.a.R.J., Profile of bioactive compounds in Syzygium cumin- a review. Journal of Pharmacy Research, 2012; 5(8):4548-4553.

2. Navnidhi Chhikara, R.K., Jaglan S, Sharma P, Gat Y and Panghal A Bioactive compounds and pharmacological and food applications of Syzygium cumini- a review. Food \& Function, 2018(12).

3. Panghal, A., et al., Nutritional, phytochemical, functional and sensorial attributes of Syzygium cumini L. pulp incorporated pasta. Food Chem, 2019; 289:723-728.

4. Gaspar, R.S., et al., Myricetin, the Main Flavonoid in Syzygium cumini Leaf, Is a Novel Inhibitor of Platelet Thiol Isomerases PDI and ERp5. Front Pharmacol, 2019. 10: p. 1678.

5. Rehman A.A., et al., In vivo assessment of anticoagulant and antiplatelet effects of Syzygium cumini leaves extract in rabbits. BMC Complement Altern Med, 2019; 19(1):236.

6. Franca L.M., et al., Syzygium cumini Leaf Extract Reverts Hypertriglyceridemia via Downregulation of the Hepatic XBP1s/PDI/MTP Axis in Monosodium L-Glutamate-Induced Obese Rats. Oxid Med Cell Longev, 2019; 2019:9417498.

7. Chagas V.T., et al., Protective Effects of a Polyphenol-Rich Extract from Syzygium cumini (L.) Skeels Leaf on Oxidative Stress-Induced Diabetic Rats. Oxid Med Cell Longev, 2018; 2018:5386079.

8. Chaudhary B, K.M., Syzygium cumini (L.) Skeels: A Potential Source of Nutraceuticals. International Journal of Pharmacy and Biological Sciences, 2012; 2(1):46-53.
9. Jadhav VM, S.S.K., V.J.. Kadam, Herbal medicine: Syzygium cumini: A Review. Journal of Pharmacy Research, 2009; 2(7):1212-1219.

10. Dixit S. and Tiwari S, Investigation of anti-diabetic plants used among the ethnic communities of Kanpur division, India. J Ethnopharmacol, 2020; 253:112639.

11. Mandal MD, S.M., and Pal NK, Antibiotic Resistance Prevalence and Pattern in Environmental Bacterial Isolates. The Open Antimicrobial Agents Journal, 2011. 3.

12. Banerjee J, N.R.T., Phytochemical Analyses, Antibacterial, In-vitro Antioxidant and cytotoxic activities of ethanolic extract of SyzygiumCumini (L.) Seed Extract. International Journal of Pharmaceutical Sciences and Research, 2011, 2(7):1799-1806.

13. Chagas V.T., et al., Syzygium cumini (L.) skeels: a prominent source of bioactive molecules against cardiometabolic diseases. Front Pharmacol, 2015; 6:259.

14. Pal AK, Nagaich U, Bharti C, Gulati N, Formulation and Evaluation of Nutraceutical Tablet using Herbal drugs by Direct Compression Method. Journal of Drug Delivery \& Therapeutics, 2014; 4(2):4751.

15. Salome AC, C.U.C.E., lkechukwu VO, Sinye AB, Calister EU, Godswill CO, Formulation and evaluation of Cymbopogon citratus dried leaf-powder tablets. African Journal of Pharmacy and Pharmacology, 2012; 6(48):3274-3279.

16. Bharadwaj Nitin, G.S., Sharma S, Design, development and evaluation of oral herbal formulations of Piper nigrum and Nyctanthes arbortristis. International Journal of PharmTech Research, 2010; 2(1):171-176.

17. Sumalatha G, J.R.G., Formulation and Evaluation of Polyherbal Chewable Tablets for reducing Nicotine dependence. International Journal of Pharmacy and Biological Sciences, 2017; 7(1):115120

18. Damle MC, Bhalekar MR, Rao S, Godse M, Formulation and Evaluation of Chewable Tablets of Pomogranate Peel Extract. Journal of Drug Delivery \& Therapeutics, 2019; 9(4):318-321.

19. Bangar Raju, M.B., Indira Bairy, A novel treatment approach towards emerging multidrug resistant Enteroaggregative Escherichia coli (EAEC) causing acute/ persistent diarrhea using medicinal plant extracts. Research Journal of Pharmaceutical, Biological andChemical Sciences, 2011; 2(1):15-23.

20. Siddig A, A.E.A., Elbadawi AA, Mustafa EM, Mussa AA, Structural Characterization and Physical Properties of Syzygium cumini Flowering Plant. International Journal of Innovative Research in Science, Engineering and Technology, 2015; 4(5):2694-2699. 